Research Article

\title{
Mesenchymal Stromal Cells Support Endometriotic Stromal Cells In Vitro
}

\author{
Fawaz Abomaray $\mathbb{D}^{\mathrm{D}}{ }^{1,2}$ Sebastian Gidlöf, ${ }^{1,3,4}$ Bartosz Bezubik, ${ }^{5}$ Mikael Engman, ${ }^{6}$ \\ and Cecilia Götherströmm $\mathbb{D D}^{1,2}$ \\ ${ }^{1}$ Division of Obstetrics and Gynecology, Department of Clinical Science, Intervention and Technology, Karolinska Institutet, \\ Stockholm, Sweden \\ ${ }^{2}$ Centre for Hematology and Regenerative Medicine, Karolinska Institutet, Stockholm, Sweden \\ ${ }^{3}$ Center for Fetal Medicine, Patient Area of Pregnancy and Childbirth, Karolinska University Hospital, Stockholm, Sweden \\ ${ }^{4}$ Department of Women's and Children's Health, Karolinska Institutet, Stockholm, Sweden \\ ${ }^{5}$ Department of Obstetrics and Gynecology, Karolinska University Hospital, Stockholm, Sweden \\ ${ }^{6}$ Department of Obstetrics and Gynecology, Danderyd's Hospital, Stockholm, Sweden
}

Correspondence should be addressed to Cecilia Götherström; cecilia.gotherstrom@ki.se

Received 3 October 2017; Revised 29 November 2017; Accepted 24 December 2017; Published 28 January 2018

Academic Editor: Essam M. Abdelalim

Copyright (C) 2018 Fawaz Abomaray et al. This is an open access article distributed under the Creative Commons Attribution License, which permits unrestricted use, distribution, and reproduction in any medium, provided the original work is properly cited.

\begin{abstract}
Endometriosis is an inflammatory disease marked by ectopic growth of endometrial cells. Mesenchymal stromal cells (MSC) have immunosuppressive properties that have been suggested as a treatment for inflammatory diseases. Therefore, the aim herein was to examine effects of allogeneic MSC on endometriosis-derived cells in vitro as a potential therapy for endometriosis. MSC from allogeneic adipose tissue (Ad-MSC) and stromal cells from endometrium $\left(\mathrm{ESC}_{\text {endo }}\right)$ and endometriotic ovarian cysts $\left(\mathrm{ESC}_{\text {cyst }}\right)$ from women with endometriosis were isolated. The effects of Ad-MSC on $\mathrm{ESC}_{\text {endo }}$ and $\mathrm{ESC}_{\text {cyst }}$ were investigated using in vitro proliferation, apoptosis, adhesion, tube formation, migration, and invasion assays. Ad-MSC significantly increased proliferation of ESC compared to untreated controls. Moreover, Ad-MSC significantly decreased apoptosis and increased survival of ESC. Ad-MSC significantly increased adhesion of $\mathrm{ESC}_{\text {endo }}$ and not $\mathrm{ESC}_{\mathrm{cyst}}$ on fibronectin. Conditioned medium from cocultures of Ad-MSC and ESC significantly increased tube formation of human umbilical vein endothelial cells on matrigel. Ad-MSC may significantly increase migration of $\mathrm{ESC}_{\text {cyst }}$ and did not increase invasion of both cell types. The data suggest that allogeneic Ad-MSC should not be considered as a potential therapy for endometriosis, because they may support the pathology by maintaining and increasing growth of ectopic endometrial tissue.
\end{abstract}

\section{Introduction}

Endometriosis affects approximately $10 \%$ of women of reproductive age, is marked with ectopically growing endometrial cells, and exhibits increased local inflammation leading to chronic pelvic pain and infertility [1]. Despite medical and surgical treatments to reduce inflammation and remove ectopic lesions, recurrence or therapy resistance is very common [2]. Therefore, there is an urgent need of new therapies for endometriosis.

Despite active research, the pathogenesis of endometriosis remains largely unclear. The most commonly accepted theory is that endometriosis develops from reflux of menstrual debris into the pelvic cavity during menstruation, which then implants resulting in endometriosis [3]. Although almost all women exhibit retrograde menstruation, only approximately $10 \%$ develop endometriosis [4]. This conundrum must be explained by other factors playing a role in disease development $[3,4]$. For example, the endometrium of women with endometriosis displays resistance to apoptosis with a subsequent increase in cell proliferation, migration, adhesion, and invasion of the mesothelial lining of the pelvic cavity and increased ability to induce angiogenesis to cause endometriosis [5]. 
The immunosuppressive properties of mesenchymal stromal cells, also called mesenchymal stem cells (MSC), have made them a potential treatment for inflammatory and autoimmune diseases such as graft versus host disease (GvHD), multiple sclerosis (MS), and Crohn's disease [6]. It has been suggested that the immunosuppressive properties of MSC are due to their ability to sense the changing levels of inflammation in their microenvironment and respond accordingly [7]. Therefore, MSC may be a potential therapy for the inflammatory component of endometriosis. More specifically, previously, it has been reported that allogeneic MSC derived from adipose tissue (Ad-MSC) have immunosuppressive properties with potential to treat inflammatory diseases such as GvHD and MS [8, 9]. Previously, it has been found that autologous MSC are altered by the pathology of endometriosis [10]. In addition, we found that MSC from the ectopic $\left(\mathrm{ESC}_{\mathrm{cyst}}\right)$ endometrium were phenotypically and functionally different from MSC from the eutopic $\left(\mathrm{ESC}_{\text {endo }}\right)$ endometrium in women with endometriosis suggesting that autologous MSC may be altered by the pathology [11]. Therefore, in the present study, we aimed to investigate the effects of allogeneic Ad-MSC on endometriosis-derived cells in vitro as the first step of a long-term goal of developing a potential therapy for endometriosis. The effects of Ad-MSC on $\mathrm{ESC}_{\text {cyst }}$ and $\mathrm{ESC}_{\text {endo }}$ were examined using proliferation, apoptosis, adhesion, tube formation (in vitro angiogenesis), migration, and invasion assays, which are the aforementioned parameters that are perturbed in endometriosis. It was found that allogeneic Ad-MSC may promote $\mathrm{ESC}_{\text {cyst }}$ proliferation, survival, and migration and support $\mathrm{ESC}_{\text {cyst }}$ to promote tube formation of human umbilical vein endothelial cells (HUVEC) but did not affect adhesion or invasion of $\mathrm{ESC}_{\text {cyst }}$ in vitro. The data suggest that allogeneic Ad-MSC should not be considered as a potential therapy for endometriosis because they may support the pathology by maintaining and increasing growth of ectopic endometrial tissue. Moreover, since MSC are present in ectopic lesions in endometriosis as confirmed by us [11] and others [12], this indicates that MSC are likely involved in the pathogenesis of endometriosis.

\section{Materials and Methods}

2.1. Human Tissue Samples. The inclusion criteria for the study were female women of fertile age suffering from endometriosis that have not undergone hormonal treatment for three to six months before undergoing laparoscopic surgery for confirmation of diagnosis and treatment. Three types of tissues were collected: (i) endometriotic ovarian cysts (ectopic endometrium) and (ii) endometrium (eutopic endometrium), which were both from women with endometriosis who underwent surgery for removal of endometriotic ovarian cysts, and (iii) adipose tissue from healthy women undergoing elective caesarean section at term. The endometriotic ovarian cysts and endometrium were collected from women aged 31 to $42(36.3 \pm 5.8$ years (mean $\pm \mathrm{SD}), n=4)$ undergoing laparoscopic surgery for confirmation or treatment of endometriosis. All women were histologically confirmed to have endometriosis by a pathologist. Only one woman underwent hormonal treatment. Moreover, two of the biopsies were from the proliferative phase, one was unknown, and one had amenorrhea. The adipose tissue was collected from women aged 34 to $39(36.5 \pm 3.54$ years (mean $\pm S D)$, $n=2)$. Informed oral and written consent was obtained from each participant, and ethical approval was obtained from The Regional Ethical Review Board in Stockholm (2013/1094-31/ 2, 2017/1017-32).

2.2. Isolation of Stromal Cells from Eutopic and Ectopic Endometrium. Human endometrial and endometriotic ovarian cyst tissues were digested to single cell suspension using $1 \mathrm{mg} / \mathrm{mL}$ collagenase type I (Sigma, Missouri, United States) diluted in Hank's Balanced Salt Solution (Life Technologies, Paisley, UK) (90 min for endometriotic tissue and $30 \mathrm{~min}$ for endometrial tissue) at $37^{\circ} \mathrm{C}$ with shaking every $10 \mathrm{~min}$. The tissue digests were filtered twice through $100 \mu \mathrm{m}$ cell strainers (Corning, New York, United States), and eventually, the stromal cells were filtered through a $40 \mu \mathrm{m}$ cell strainer (Corning), with undigested tissue and epithelial cells being removed at each of the steps. The cell suspension was washed twice with phosphate-buffered saline (PBS) (Life technologies) by centrifugation at $500 \times \mathrm{g}$ for $10 \mathrm{~min}$. Finally, the cell pellet was resuspended in complete growth medium containing Dulbecco modified essential medium low glucose (DMEM-LG) (Life technologies) + 10\% MSC certified fetal calf serum (FCS) (Life technologies) + 1\% antibiotic and antimycotic (Life technologies). Viable cells were counted in 1\% eosin (Merck KGaA, Darmstadt, Germany) and cultured at 4000 cells $/ \mathrm{cm}^{2}$ in tissue culture flasks at $37^{\circ} \mathrm{C}$ with $5 \% \mathrm{CO}_{2}$. After two days, the growth medium was changed and thereafter every three to four days. When the cells reached 70-90\% confluency, they were trypsinised using $0.05 \%$ trypsin/EDTA (Life technologies) and cultured as described above. At passage 2, the stromal cells were cryopreserved in $10 \%$ dimethyl sulfoxide (DMSO) (Sigma) in complete growth medium. Flow cytometry showed that they were positive for stromal markers, such as CD73, CD90, and CD105 (data not shown). To ensure that we were working with a pure population of cells, $\mathrm{ESC}_{\text {endo }}$ and $\mathrm{ESC}_{\text {cyst }}$ were used at passages three to six, as earlier passages may be contaminated with other cell types.

2.3. Isolation of Allogeneic Ad-MSC from Adipose Tissue. Human adipose tissue was obtained from healthy pregnant women undergoing elective caesarean section. The tissue was digested as described above but for $60 \mathrm{~min}$. The tissue digest was centrifuged at $500 \times \mathrm{g}$ for $10 \mathrm{~min}$ at $4^{\circ} \mathrm{C}$. Following centrifugation, the top layer of fat and middle layer of blood were carefully removed, with the resulting cell pellet resuspended in complete growth medium as described above. The stromal cells were cultured and cryopreserved as described above. These Ad-MSC were characterized by flow cytometry for CD73, CD90, CD105, HLA classes I and II, CD14, CD45, and CD31; formation of colonies in colonyforming units-fibroblasts; and differentiation assays into the osteogenic and adipogenic mesenchymal lineages and were found to be MSC [13]. To ensure that we were working with a pure population of cells, Ad-MSC was used at passages 


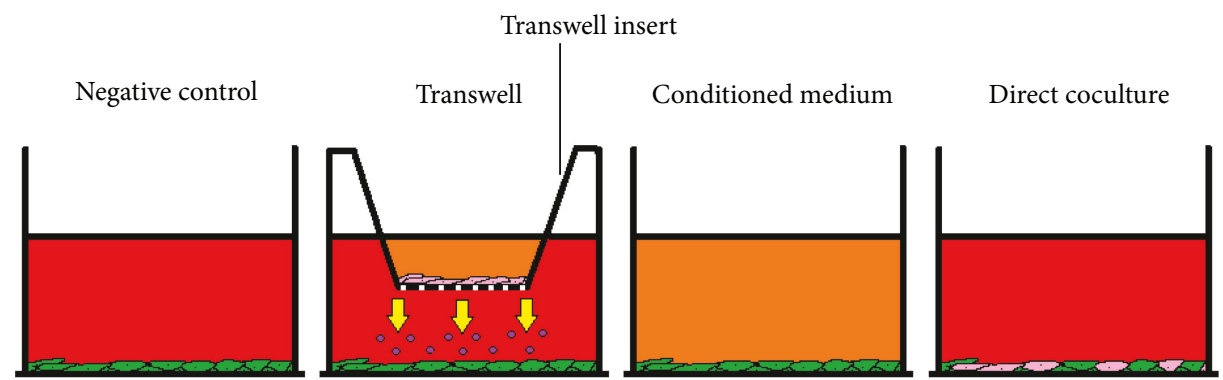

(a)

(b)

(c)

(d)

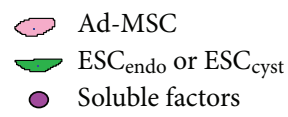

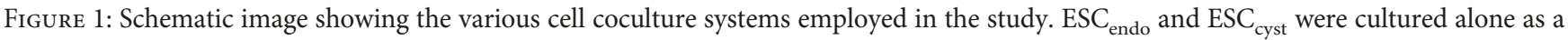
negative control (Neg C), with Ad-MSC using $0.4 \mu \mathrm{m}$ pore inserts as a transwell system in conditioned medium (Cond) derived from Ad-MSC, or with Ad-MSC in direct cell coculture (Direct).

three to six, as earlier passages may be contaminated with other cell types.

2.4. Cell Coculture Setup. Ad-MSC were investigated for their effects on $\mathrm{ESC}_{\text {endo }}$ and $\mathrm{ECS}_{\text {cyst }}$ using cell proliferation, apoptosis, adhesion, migration, and invasion assays. Based on optimization experiments a $1: 1$ ratio of Ad-MSC to ESC $_{\text {endo }}$ and ESC $_{\text {cyst }}$ was selected for the transwell and direct cell coculture experiments (data not shown); the number of cells used were optimized to be within the optimum capacity of the inserts (an insert can hold up to $1.12 \times 10^{5}$ cells) and the bottom wells (a well can hold up to $3.8 \times 10^{5}$ cells) according to Corning. The different cell coculture systems that were employed in the study are shown in Figure 1; each of the cell coculture systems mimic the effects MSC may potentially be causing in vivo, and therefore, they are all representative and hence essential to give an overall picture of the potential effects of MSC.

In the eosin exclusion assay, unprimed Ad-MSC and AdMSC primed with interferon gamma (IFN- $\gamma$ ) $(100 \mathrm{U} / \mathrm{mL}$, Sigma) or IFN- $\gamma(100 \mathrm{U} / \mathrm{mL})+$ tumor necrosis factor alpha (TNF- $\alpha)(10 \mathrm{ng} / \mathrm{mL}$, PeproTech, London, UK) and their conditioned medium were used. MSC can be primed using proinflammatory cytokines such as IFN- $\gamma$ and TNF- $\alpha$, to make them more immunosuppressive and secrete more immunosuppressive factors, which means that they may be more therapeutically effective for a disease with an inflammatory basis such as endometriosis $[14,15]$. Therefore, we examined if priming Ad-MSC to become more immunosuppressive would give an effect that would be different to unprimed MSC. For the carboxyfluorescein succinimidyl ester (CFSE), MTT (3-(4,5-dimethylthiazol-2-yl)-2,5-diphenyltetrazolium bromide), apoptosis, adhesion, tube formation, migration, and invasion assays, only unprimed Ad-MSC were used. This is because primed Ad-MSC had no effect on the proliferation of $\mathrm{ESC}_{\text {endo }}$ and $\mathrm{ESC}_{\text {cyst }}$ compared to unprimed Ad-MSC.

The following cell coculture setup was used, with slight modifications for each of the assays. When Ad-MSC were $\sim 70 \%$ confluent, the growth medium was removed, the cells were washed twice with PBS and growth medium alone, or growth medium with IFN- $\gamma$, or growth medium with IFN- $\gamma+$ TNF- $\alpha$ were added. After three days, the conditioned medium was collected, Ad-MSC harvested, and were irradiated at $20 \mathrm{~Gy}$ to inhibit their proliferation. The conditioned medium was centrifuged at $500 \times \mathrm{g}$ for $10 \mathrm{~min}$ to remove cellular debris, aliquoted, and frozen at $-80^{\circ} \mathrm{C}$. $\mathrm{ESC}_{\text {endo }}$ and $\mathrm{ESC}_{\text {cyst }}$ were harvested and added to 12-well plates at 6000 cells $/ \mathrm{cm}^{2}$. An equal amount of irradiated AdMSC was added to transwell inserts with a $0.4 \mu \mathrm{m}$ pore size (Corning) and placed in the wells with $\mathrm{ESC}_{\text {endo }}$ or $\mathrm{ESC}_{\text {cyst }}$ for direct cell coculture. Conditioned medium from AdMSC was also used, and untreated $\mathrm{ESC}_{\text {endo }}$ or $\mathrm{ESC}_{\text {cyst }}$ were used as controls. After 3 days of cell culture, the proliferation, apoptosis, adhesion, migration, or invasion of $\mathrm{ESC}_{\text {endo }}$ and ESC $_{\text {cyst }}$ were quantified as described below.

2.5. Cell Proliferation Assays. Cell proliferation was measured using three different methods in order to confirm the data: the manual eosin exclusion, CFSE, and MTT assays. For the eosin exclusion assay, the total number of cells were counted using $1 \%$ eosin.

For the CFSE assay, $\mathrm{ESC}_{\text {endo }}$ and $\mathrm{ESC}_{\mathrm{cyst}}$ were stained with $1 \mu \mathrm{M}$ CFSE (Life Technologies) for $10 \mathrm{~min}$ at $37^{\circ} \mathrm{C}$ with $5 \% \mathrm{CO}_{2}$ as described previously [16], before they were added in the 12-well plates as above. The cells were incubated with $5 \mathrm{~mL}$ of complete growth medium for $10 \mathrm{~min}$ at $37^{\circ} \mathrm{C}$ with $5 \%$ $\mathrm{CO}_{2}$ to quench the reaction and to remove the remaining free dye. The cells were washed three times, resuspended in complete growth medium, and kept for $10 \mathrm{~min}$ at $37^{\circ} \mathrm{C}$ with $5 \%$ $\mathrm{CO}_{2}$ to allow the CFSE stain to undergo acetate hydrolysis. On day 0, CFSE-stained $\mathrm{ESC}_{\text {endo }}$ and $\mathrm{ESC}_{\text {cyst }}$ were used to set voltages on the BD FACSCalibur (Becton-Dickinson, New Jersey, United States) to ensure the cells were on the far right of the CFSE histograms. After 3 days of cell culture, $\mathrm{ESC}_{\text {endo }}$ and $\mathrm{ESC}_{\text {cyst }}$ were harvested and analyzed on a $\mathrm{BD}$ FACSCalibur. As described previously, the data was analyzed using the median fluorescence intensity (MFI) with the software FlowJo (Tree Star version 10.1r5 Inc., Ashland, United States), with a lower MFI representing greater cell 
proliferation and dilution of the CFSE dye [17]. For direct cell coculture, gating was only on the CFSE-positive $\mathrm{ESC}_{\text {endo }}$ and ESC $_{\text {cyst. }}$ The results are shown relative to the untreated controls (ESC alone).

For the MTT assay, after 3 days of cell culture, the growth medium was removed, centrifuged at $500 \times \mathrm{g}$ for $10 \mathrm{~min}$ to remove cellular debris, aliquoted, and frozen at $-80^{\circ} \mathrm{C}$, for later use in the tube formation assay (see below). Then, $\mathrm{ESC}_{\text {endo }}$ and $\mathrm{ESC}_{\text {cyst }}$ were stained with $0.5 \mathrm{mg} / \mathrm{mL} \mathrm{MTT}$ reagent (Life Technologies) for 4 hours at $37^{\circ} \mathrm{C}$ with $5 \%$ $\mathrm{CO}_{2}$. Afterwards, the MTT reagent was removed, the MTT crystals were solubilized in dimethyl sulfoxide (DMSO), and the plates were kept at $37^{\circ} \mathrm{C}$ with $5 \% \mathrm{CO}_{2}$ for $10 \mathrm{~min}$. Then, the absorbance was measured at $540 \mathrm{~nm}$ using the infinite F200 Pro Tecan spectrophotometer (Tecan, Mannedorf, Switzerland), with DMSO used as a blank. The absorbance for irradiated Ad-MSC cultured alone was subtracted from the absorbance of the direct cell coculture wells to account for the absorbance of $\mathrm{ESC}_{\text {endo }}$ and $\mathrm{ESC}_{\text {cyst }}$ only.

2.6. Analysis of Apoptosis with Annexin V Assay. The annexin $\mathrm{V}$ assay was used to analyze apoptosis, as previously described [18], of $\mathrm{ESC}_{\text {endo }}$ and $\mathrm{ESC}_{\text {cyst }}$, which were stained with CFSE as described above before they were added to 12-well plates and cultured with irradiated Ad-MSC. After 3 days of cell culture, $\mathrm{ESC}_{\text {endo }}$ and $\mathrm{ESC}_{\text {cyst }}$ were harvested and resuspended in $100 \mu \mathrm{L}$ annexin $\mathrm{V}$ binding buffer (10 mM of 4-(2-hydroxyethyl)-1-piperazineethanesulfonic acid (Life technologies) $+140 \mathrm{mM}$ of sodium chloride (Sigma) $+2.5 \mathrm{mM}$ of calcium chloride (Sigma)). Then, the cells were stained with annexin V PE antibody (BioLegend, California, United States) and 7-AAD (BD Biosciences, Stockholm, Sweden) for $15 \mathrm{~min}$ at room temperature (RT) in the dark. Then, $400 \mu \mathrm{L}$ annexin $\mathrm{V}$ binding buffer was added and the CFSE positive cells were analyzed on a BD LSR Fortessa (Becton-Dickinson). For direct cell coculture, gating was only on the CFSE-positive $\mathrm{ESC}_{\text {endo }}$ and $\mathrm{ESC}_{\text {cyst }}$. The data was analyzed using the software FlowJo.

2.7. Cell Adhesion Assay. Tissue culture-treated 48-well plates (Corning) were prepared by coating overnight with $10 \mu \mathrm{g} / \mathrm{mL}$ human fibronectin (BD Biosciences) at $4^{\circ} \mathrm{C}$, and the cell adhesion assay was carried out as previously described [19]. The remaining sites were blocked with $0.1 \%$ bovine serum albumin (Sigma) for 2 hours at RT and washed once with PBS. The 48-well plates were dried and wrapped in parafilm and stored at $4^{\circ} \mathrm{C}$ until use for the cell adhesion assay.

After 3 days of cell culture as described above, $\mathrm{ESC}_{\text {endo }}$ and ESC $_{\text {cyst }}$ were harvested and counted. The fibronectin-coated plates were brought to RT for at least $10 \mathrm{~min}$. $\mathrm{ESC}_{\text {endo }}$ and ESCcyst were resuspended in serum-free DMDM-LG medium and seeded at 21000 cells $/ \mathrm{cm}^{2}$. Following 2 hours of cell adhesion at $37^{\circ} \mathrm{C}$ with $5 \% \mathrm{CO}_{2}$, the medium was gently removed, and the wells were washed with PBS containing $2 \mathrm{mM}$ calcium chloride and $2 \mathrm{mM}$ magnesium chloride. The remaining adherent cells were quantified using the MTT assay as described above.

2.8. Tube Formation Assay. The tube formation assay was carried out as previously described [20]. HUVEC were kindly provided by Dr. Nina Heldring (Karolinska Institutet). They were isolated $(n=2)$ as previously described [21] and expanded on $0.1 \%$ gelatin- (Kodak) coated surfaces in complete HUVEC growth medium containing human endothelial serum-free basal medium (Fisher Scientific, Göteborg, Sweden) $+10 \%$ FCS (Life technologies) $+1 \%$ penicillin and streptomycin (Life technologies). They were used for experiments at passages two to five. For the tube formation assay, all pipette tips and plates were prechilled at $-20^{\circ} \mathrm{C}$. Matrigel (Corning) was thawed overnight at $4^{\circ} \mathrm{C}$ on ice, aliquoted at $50 \mu \mathrm{L}$ per well in 96 -well plates, and kept at $37^{\circ} \mathrm{C}$ with $5 \%$ $\mathrm{CO}_{2}$ for 1 hour in order for the matrigel to gel. HUVEC were harvested and counted with eosin as described above, then $20 \times 10^{3}$ were resuspended in 50\% complete HUVEC growth medium $+50 \%$ conditioned medium collected from the MTT assay (see above) and added gently on the matrigel. The cells were kept at $37^{\circ} \mathrm{C}$ with $5 \% \mathrm{CO}_{2}$ for $17-18$ hours, then they were visualized using the Olympus CKX41 inverted microscope (Olympus, Tokyo, Japan), and images were taken at $4 \mathrm{x}$ magnification capturing the whole well in the 96-well plates. The number of tubes formed per well were quantified by using the angiogenesis analyzer plugin on ImageJ (Version 1.48, National Institutes of Health, Bethesda, United States) as described previously [22].

2.9. Cell Migration Assay. The transwell cell migration assay was carried out as previously described [23]. After 3 days of cell culture as described above, $\mathrm{ESC}_{\text {endo }}$ and $\mathrm{ESC}_{\text {cyst }}$ were harvested and counted. $\mathrm{ESC}_{\text {endo }}$ and $\mathrm{ESC}_{\text {cyst }}$ were added at $25 \times 10^{3}$ per transwell insert ( $8 \mu \mathrm{m}$ in pore diameter, Corning) in serum-free DMEM-LG growth medium in 24-well plates and were allowed to migrate towards 10\% FCS in DMEMLG growth medium at $37^{\circ} \mathrm{C}$ with $5 \% \mathrm{CO}_{2}$. The negative controls were untreated $\mathrm{ESC}_{\text {endo }}$ and $\mathrm{ESC}_{\text {cyst }}$. After 20 hours, the nonmigrated cells on top of the inserts were removed using a wet cotton swab, the inserts washed with PBS, and the cells fixed with ice cold methanol for 5 minutes. The inserts were again washed with PBS, before being stained with $1 \%$ eosin for 1 hour. Finally, the inserts were washed in milliQ water and dried and 5 random fields per insert of the migrated cells were captured at $10 \mathrm{x}$ magnification. The number of cells that migrated were analyzed and counted using ImageJ.

2.10. Cell Invasion Assay. The transwell cell invasion assay was carried out as previously described [23]. After 3 days of cell culture as described above, $\mathrm{ESC}_{\text {endo }}$ and $\mathrm{ESC}_{\text {cyst }}$ were harvested and counted. On the same day, transwell inserts $(8 \mu \mathrm{m}$ in pore diameter, Corning) fitting 24 -well plates were coated with $0.1 \mathrm{mg} / \mathrm{mL}$ matrigel for two hours. $\mathrm{ESC}_{\text {endo }}$ and $\mathrm{ESC}_{\text {cyst }}$ were added at $25 \times 10^{3}$ per insert in serum-free DMEM-LG growth medium, placed in the 24 -well plates and allowed to invade through matrigel towards $10 \%$ FCS in DMEM-LG growth medium at $37^{\circ} \mathrm{C}$ with $5 \% \mathrm{CO}_{2}$. The negative controls were untreated $\mathrm{ESC}_{\text {endo }}$ or $\mathrm{ESC}_{\text {cyst. }}$. After 20 hours, the invaded cells were stained and quantified as described above for the migration assay.

2.11. Statistical Analysis. All statistical analyses were performed using GraphPad prism 6. When data was normally 

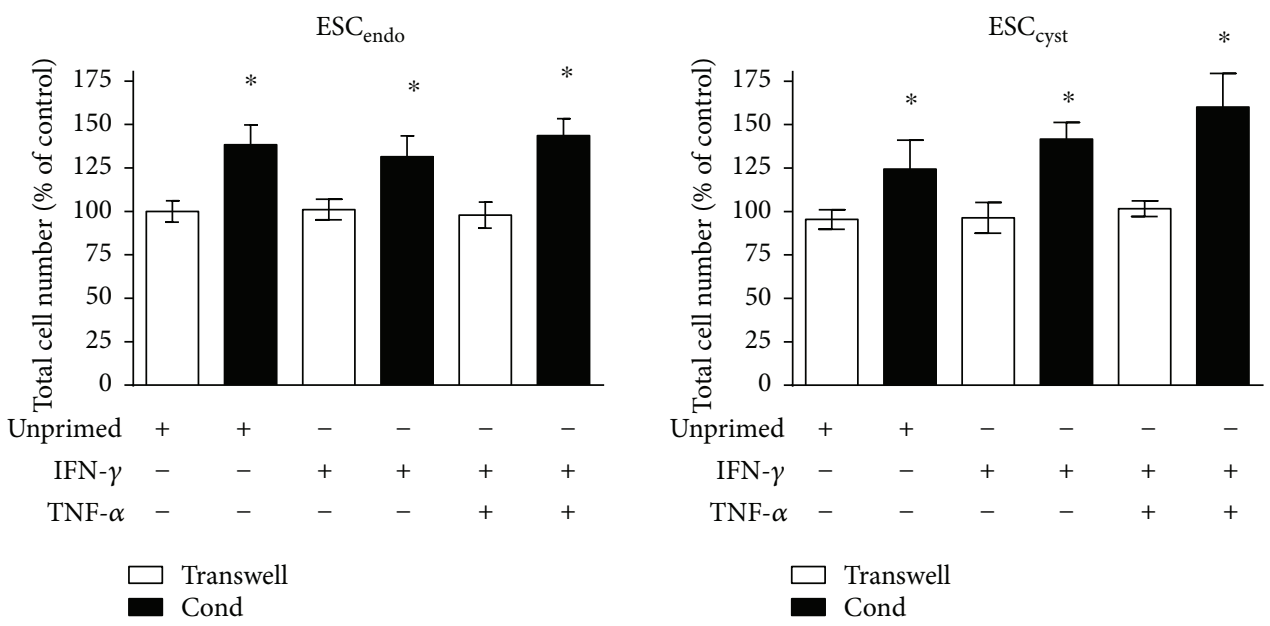

(a)
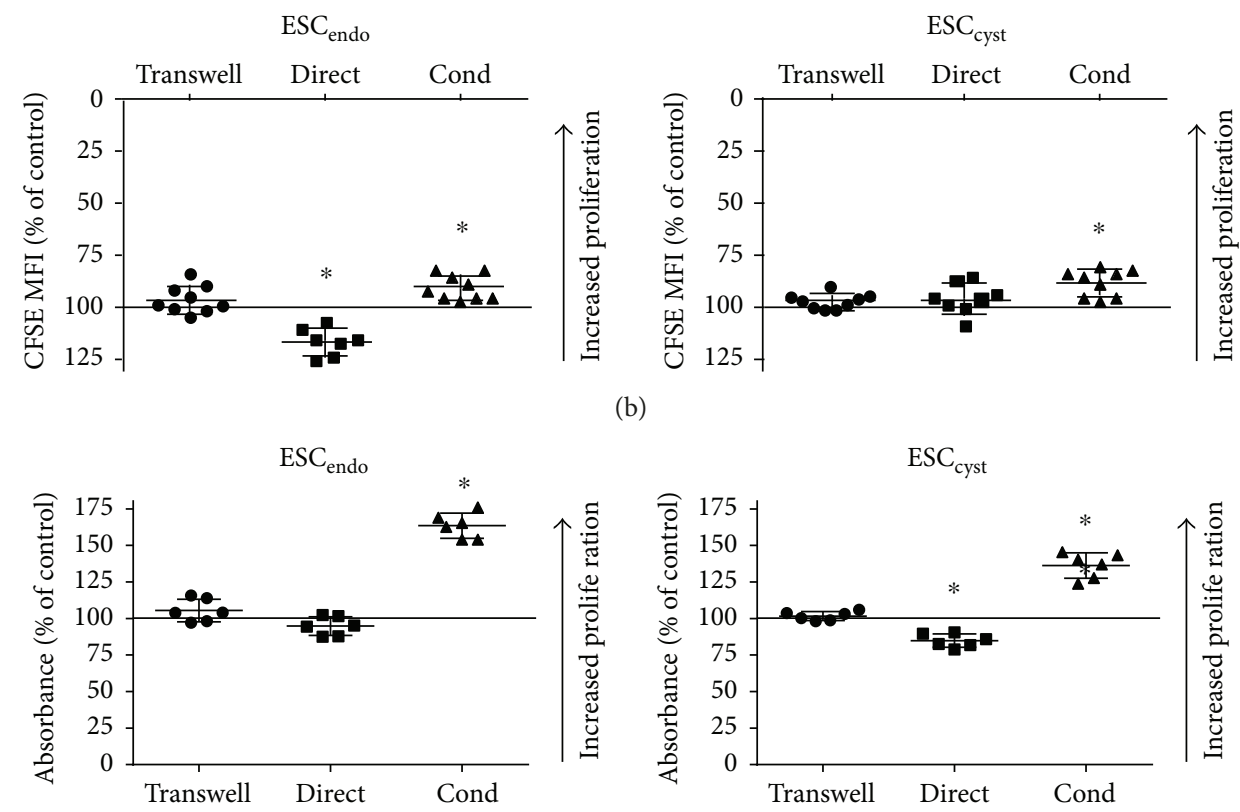

(c)

FIGURE 2: Ad-MSC increased proliferation of $\mathrm{ESC}_{\text {endo }}$ and $\mathrm{ESC}_{\mathrm{cyst}}$. A transwell system using Ad-MSC and conditioned medium (Cond) from allogeneic unprimed and primed ( $100 \mathrm{U} / \mathrm{mL}$ IFN $-\gamma$ or $100 \mathrm{U} / \mathrm{mL}$ IFN- $\gamma+10 \mathrm{ng} / \mathrm{mL}$ TNF- $\alpha$ ) Ad-MSC were used in coculture with ESC endo $_{\text {or }}$

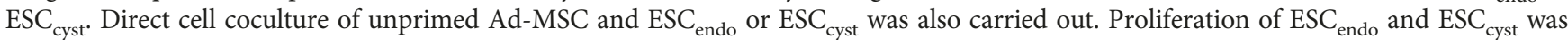
determined using the eosin exclusion (a), CFSE (b), and MTT (c) assays. Conditioned medium increased proliferation of ESC endo and ESC $_{\text {cyst }}\left({ }^{*} P<0.05\right)$, and the transwell system had no effect on the proliferation of both cell types. The effect of direct cell coculture was more ambiguous. The data was normalized to untreated controls for each cell type. Thirty-six independent experiments $(n=3-4$ biological replicates) were carried out in duplicates (mean $\pm \mathrm{SD}$ ).

distributed, the means were analyzed with Student's $t$-test, and when it was not normally distributed, the medians were analyzed with the Mann-Whitney test. All values are shown as the mean \pm standard deviations (SD). For the study, $n$ refers to the number of biological replicates. Results were considered to be statistically significant if $P<0.05$.

\section{Results}

3.1. Ad-MSC Increased Proliferation of Stromal Cells. To study the effects of Ad-MSC on stromal cell proliferation, Ad-MSC were cocultured with ESC directly or in a transwell system, or the effects of conditioned medium from Ad-MSC (either primed or unprimed with IFN- $\gamma$ or IFN- $\gamma+$ TNF- $\alpha$ ) on stromal cells was examined. Cell proliferation was measured by the manual cell count, CFSE, and MTT assays.

Manual cell count showed that both unprimed and primed conditioned medium from Ad-MSC increased proliferation significantly $(P<0.05)$ for $\mathrm{ESC}_{\text {endo }}$ and $\mathrm{ESC}_{\text {cyst }}$ compared to the untreated controls (Figure 2(a)). Moreover, the CFSE and MTT assays also showed that conditioned medium from unprimed Ad-MSC increased proliferation significantly $(P<0.05)$ for $\mathrm{ESC}_{\text {endo }}$ and $\mathrm{ESC}_{\text {cyst }}$ compared to the untreated controls (Figures 2(b) and 2(c)). However, in the transwell 


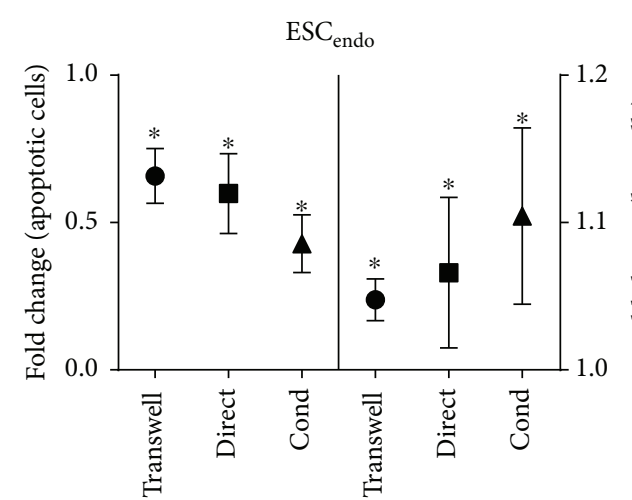

(a)

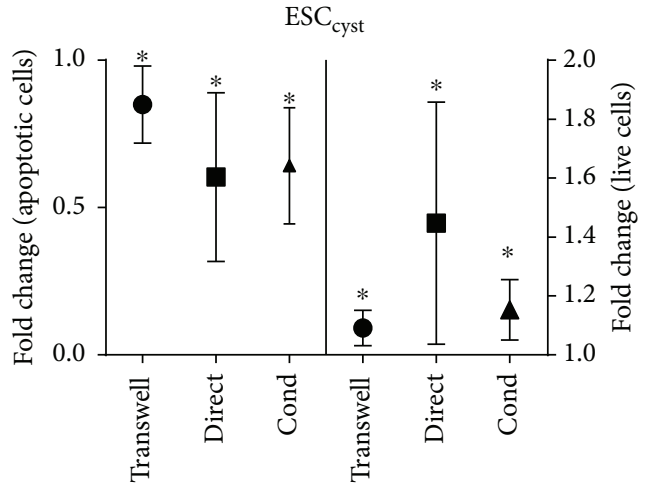

(b)

Figure 3: Ad-MSC reduced apoptosis and increased survival of $\mathrm{ESC}_{\text {endo }}$ and $\mathrm{ESC}_{\mathrm{cys}}$. $^{\mathrm{A}}$ transwell system using Ad-MSC and conditioned

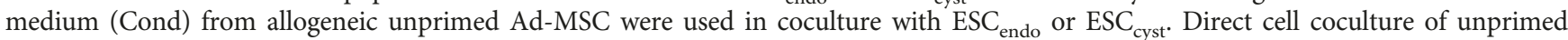
Ad-MSC and $\mathrm{ESC}_{\text {endo }}$ or $\mathrm{ESC}_{\text {cyst }}$ was also carried out. Apoptosis and survival of $\mathrm{ESC}_{\text {endo }}$ and $\mathrm{ESC}_{\text {cyst }}$ was determined using the annexin $\mathrm{V}$ assay by flow cytometry. All three systems reduced apoptosis and increased survival of $\mathrm{ESC}_{\text {endo }}$ and $\mathrm{ESC}_{\mathrm{cyst}}\left({ }^{*} P<0.05\right)$. The data was normalized to untreated controls for each cell type. Four independent experiments $(n=4$ biological replicates) were carried out in triplicates (mean $\pm \mathrm{SD})$.

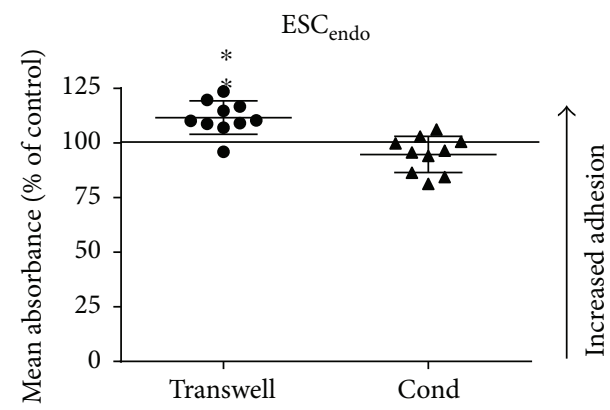

(a)

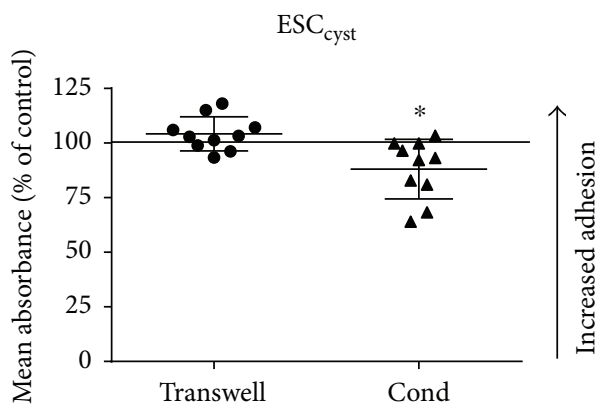

(b)

Figure 4: Ad-MSC did not increase adhesion of $\mathrm{ESC}_{\text {cyst }}$. A transwell system using Ad-MSC and conditioned medium (Cond) from allogeneic Ad-MSC were used in coculture with $\mathrm{ESC}_{\text {endo }}$ or $\mathrm{ESC}_{\mathrm{cyst}}$. Adhesion of $\mathrm{ESC}_{\text {endo }}$ and $\mathrm{ESC}_{\text {cyst }}$ on fibronectin was determined by quantifying the number of adherent cells using the MTT assay. The transwell system increased adhesion of $\mathrm{ESC}_{\text {endo }}\left({ }^{*} P<0.05\right)$, and conditioned medium reduced adhesion of $\mathrm{ESC}_{\text {cyst }}\left({ }^{*} P<0.05\right)$. The data was normalized to untreated controls for each cell type. Five independent experiments ( $n=4$ biological replicates) were carried out in duplicates (mean $\pm \mathrm{SD}$ ).

system, there was no effect on the proliferation of $\mathrm{ESC}_{\text {endo }}$ and $\mathrm{ESC}_{\text {cyst }}$ using manual cell count, CFSE, or the MTT assays (Figure 2). As measured by the CFSE assay, direct cell coculture decreased proliferation significantly $(P<0.05)$ for $\mathrm{ESC}_{\text {endo }}$ but had no effect on $\mathrm{ESC}_{\text {cyst }}$ (Figure 2(b)). On the contrary, using the MTT assay, the direct cell coculture system significantly $(P<0.05)$ decreased proliferation for ESC $_{\text {cyst }}$ but had no effect on ESC $_{\text {endo }}$ (Figure 2(c)). Priming Ad-MSC with the proinflammatory cytokines IFN- $\gamma$ and TNF- $\alpha$ resulted in no difference on cell proliferation compared to unprimed Ad-MSC, and therefore, priming was discontinued for the rest of the study. Taken together, the results showed that conditioned medium from Ad-MSC increased proliferation of ESC, and the transwell system had no effect on the proliferation of ESC. The effect of direct cell coculture was more ambiguous.

3.2. Ad-MSC Increased Survival of Stromal Cells. To examine the effects of Ad-MSC on the survival and apoptosis of
$\mathrm{ESC}_{\text {endo }}$ and $\mathrm{ESC}_{\mathrm{cyst}}$, the annexin $\mathrm{V}$ assay using flow cytometry was used. The transwell system, conditioned medium, and direct cell coculture significantly $(P<0.05)$ reduced apoptosis and increased survival for both $\mathrm{ESC}_{\text {endo }}$ and $\mathrm{ESC}_{\text {cyst }}$ compared to the untreated controls (Figure 3).

3.3. Ad-MSC Did Not Increase Adhesion of ESC $C_{c y s t}$ To examine the effects of Ad-MSC on the adhesion of ESC $_{\text {endo }}$ and $\mathrm{ESC}_{\text {cyst }}$, a fibronectin adhesion assay was employed. The transwell system increased adhesion significantly $(P<0.05)$ for $\mathrm{ESC}_{\text {endo }}$ but had no effect on $\mathrm{ESC}_{\text {cyst }}$ compared to the untreated controls (Figure 4(a)). In contrast, the conditioned medium system decreased adhesion significantly $(P<0.05)$ for $\mathrm{ESC}_{\text {cyst }}$ but had no effect on $\mathrm{ESC}_{\text {endo }}$ compared to the untreated controls (Figure 4(b)). Therefore, it can be concluded that the adhesion of $\mathrm{ESC}_{\text {cyst }}$ is not increased following treatment with Ad-MSC. Moreover, although the conditioned medium reduced the adhesion of $\mathrm{ESC}_{\text {cyst }}$, the transwell system maintained the adhesion of $\mathrm{ESC}_{\mathrm{cyst}}$, which does 

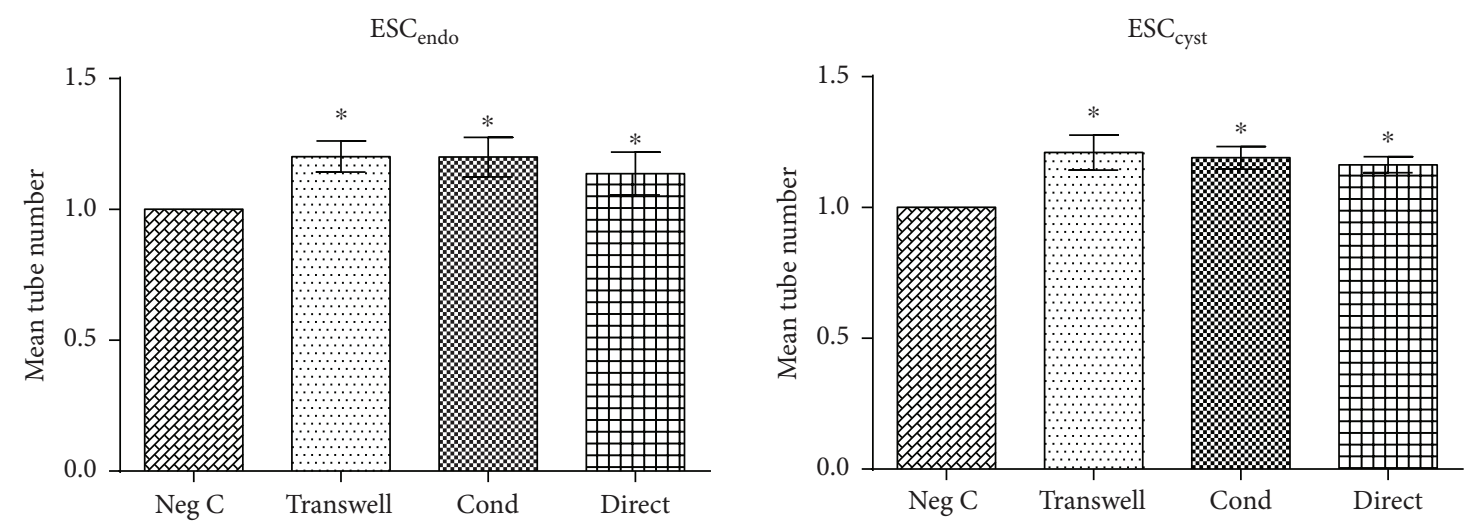

(a)
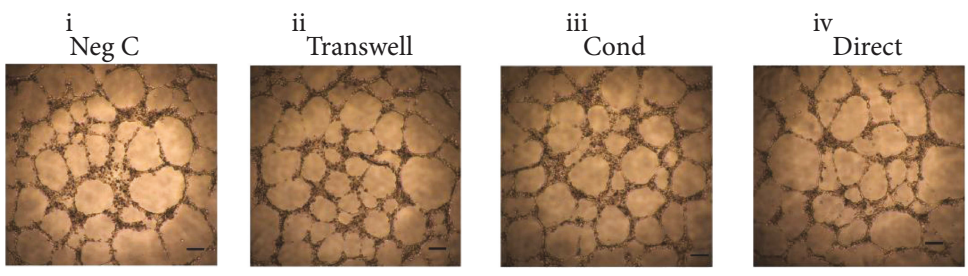

(b)

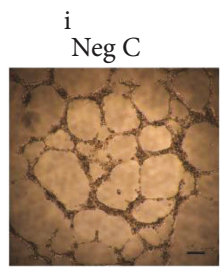

ii

Transwell



iii

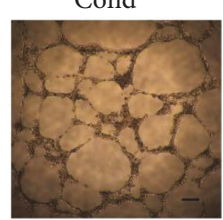

iv

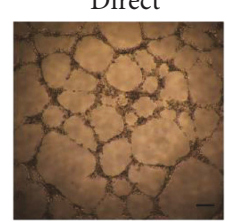

(c)

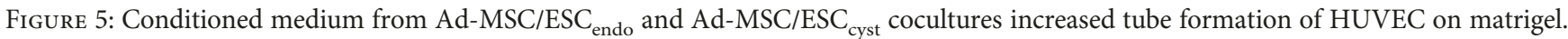
HUVEC were cultured on matrigel for 17-18 hours in conditioned medium (Cond) from cell cocultures of allogeneic Ad-MSC/ESC endo $_{\text {or }}$ Ad-MSC/ESC $C_{\text {cyst }}$, and tube formation was determined. All conditions induced tube formation (a) $\left({ }^{*} P<0.05\right)$. Representative images

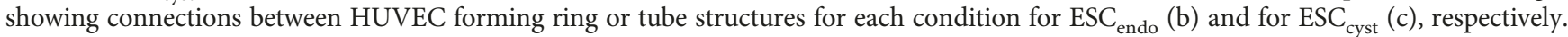
The images are at $4 \mathrm{x}$ magnification to image and quantify the whole 96-plate well. The data was normalized to untreated controls for each cell type. Four independent experiments $(n=4$ biological replicates) were carried out in duplicates (mean \pm SD). Scale bars represent $50 \mu \mathrm{m}$ at $4 \mathrm{x}$ magnification.

not support our assumption that Ad-MSC may be therapeutically useful for endometriosis.

3.4. Ad-MSC Increased Tube Formation. To evaluate the influence of Ad-MSC on tube formation of HUVEC, the effects of conditioned medium collected from the Ad-MSC/

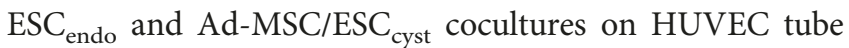
formation was studied. Conditioned medium from all three systems induced a significant $(P<0.05)$ increase in tube formation compared to the untreated controls for both $\mathrm{ESC}_{\text {endo }}$ and $\mathrm{ESC}_{\text {cyst }}$, respectively (Figure 5(a)). This shows that conditioned medium derived from cocultures of Ad-MSC and ESC can support tube formation of HUVEC in vitro.

3.5. Ad-MSC May Promote Migration of ESC ${ }_{c y s t}$. To investigate the migratory activity of ESC, they were allowed to migrate towards $10 \%$ FCS through $8 \mu \mathrm{m}$ pore filters after being treated with conditioned medium or in a transwell system with Ad-MSC. The transwell system increased ESC $_{\text {cyst }}$ migration significantly $(P<0.05)$ but had no effect on
ESC $_{\text {endo }}$ compared to the untreated controls (Figure 6(a), i). Moreover, the conditioned medium system reduced migration of both $\mathrm{ESC}_{\text {endo }}$ and $\mathrm{ESC}_{\text {cyst }}$ significantly $(P<0.05)$ compared to the untreated controls (Figure 6(a), ii). The results on the effects of Ad-MSC on $\mathrm{ESC}_{\text {cyst }}$ migration were conflicting; however, it may be concluded that Ad-MSC may promote migration of $\mathrm{ESC}_{\text {cyst }}$.

3.6. Ad-MSC Did Not Increase Invasion of ESC $\mathrm{Endo}_{\text {and }}$ $E S C_{c y s t}$. To determine the invasive capacity of $\mathrm{ESC}_{\text {endo }}$ and ESC $_{\text {cyst }}$, invasion was analyzed using a matrigel transwell assay. The transwell system had no effect on the invasive capacity of $\mathrm{ESC}_{\text {endo }}$ and $\mathrm{ESC}_{\text {cyst }}$ compared to the untreated controls (Figure $7(\mathrm{a}), \mathrm{i})$. Contrary to this, conditioned medium reduced invasion of both $\mathrm{ESC}_{\text {endo }}$ and $\mathrm{ESC}_{\mathrm{cyst}}$ significantly $(P<0.05)$ compared to the untreated controls (Figure 7(a), ii). Therefore, it can be concluded that the invasion of $\mathrm{ESC}_{\text {endo }}$ and $\mathrm{ESC}_{\text {cyst }}$ is not increased following treatment with Ad-MSC. Moreover, although the conditioned medium reduced the invasion of $\mathrm{ESC}_{\text {endo }}$ and $\mathrm{ESC}_{\text {cyst }}$, the 

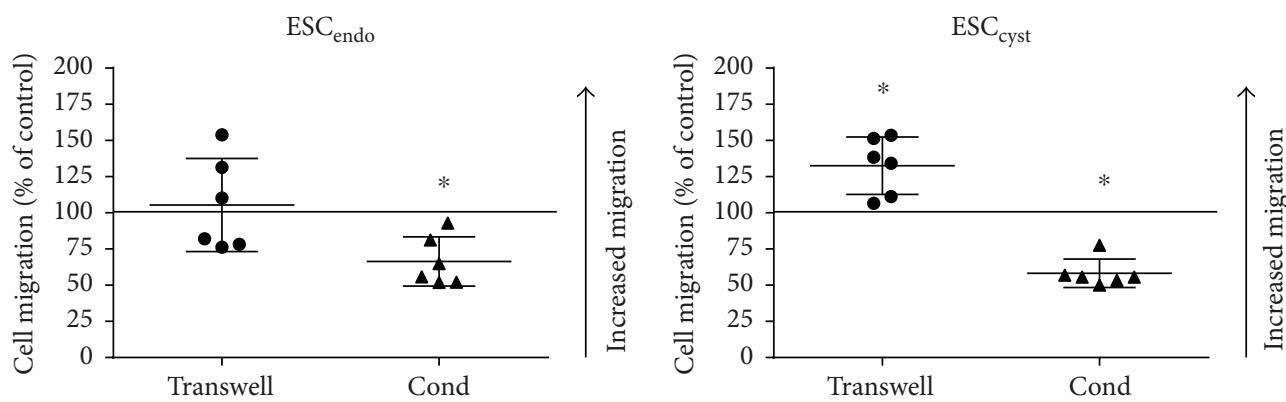

(a)
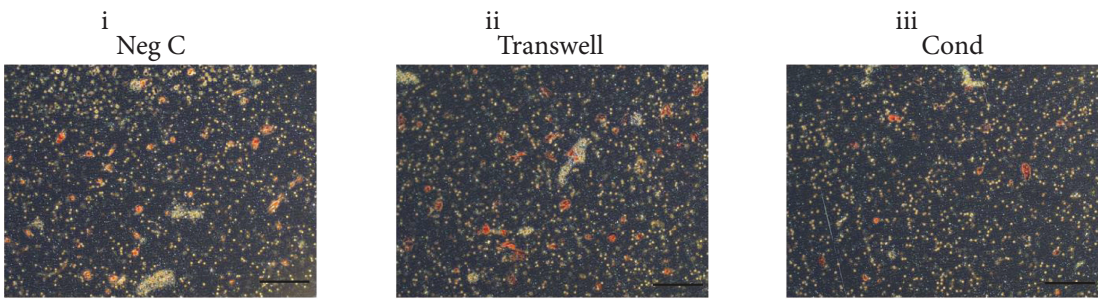

(b)
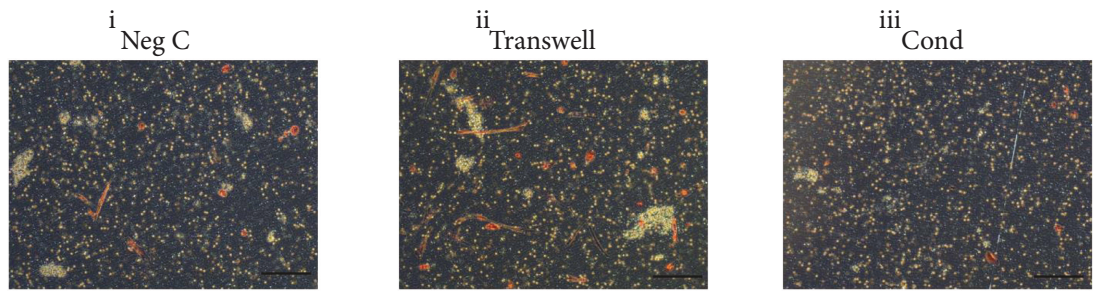

(c)

Figure 6: Ad-MSC may promote migration of ESC $_{\text {cyst }}$. A transwell system using Ad-MSC and conditioned medium (Cond) from allogeneic

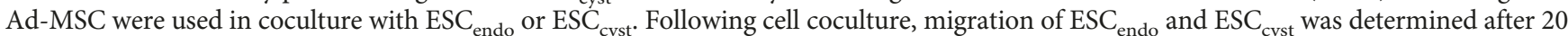
hours using the transwell migration assay. Conditioned medium reduced migration of $\mathrm{ESC}_{\text {endo }}\left({ }^{*} P<0.05\right)$. The transwell system increased migration, and conditioned medium reduced migration of $\mathrm{ESC}_{\mathrm{cyst}}\left({ }^{*} P<0.05\right)$. Representative images of migration for each condition for $\mathrm{ESC}_{\text {endo }}(\mathrm{b})$ and $\mathrm{ESC}_{\text {cyst }}$ (c). The $0.4 \mu \mathrm{m}$ pores of the inserts are the white dots, and the migrated cells are light/dark red in color (10x magnification). The data was normalized to untreated controls for each cell type. Three independent experiments $(n=3$ biological replicates) were carried out in duplicates (mean \pm SD).

transwell system maintained the invasion of both cell types, which does not support our assumption that Ad-MSC may be therapeutically useful for endometriosis.

\section{Discussion}

In this study, we show that allogeneic Ad-MSC may promote $\mathrm{ESC}_{\text {cyst }}$ proliferation, survival, and migration, and may support $\mathrm{ESC}_{\text {cyst }}$ to increase tube formation of HUVEC but did not increase adhesion or invasion of $\mathrm{ESC}_{\text {cyst }}$ in vitro. The effects of Ad-MSC on $\mathrm{ESC}_{\text {cyst }}$ shown here suggest that they should not be considered as a potential therapy for endometriosis, because they may support the pathology of endometriosis by maintaining and increasing growth of ectopic endometrial tissue. Moreover, since MSC are present in ectopic lesions in endometriosis as confirmed by us [11] and others [12], this indicates that MSC are likely involved in the pathogenesis of endometriosis.

Li et al. studied the effect of conditioned medium from MSC on $\mathrm{ESC}_{\text {endo }}$ and $\mathrm{ESC}_{\text {cyst }}$, and similar to our data, they found that MSC induce a significant increase in ESC proliferation [24]. Also, MSC isolated from Wharton's jelly induced a significant increase in $\mathrm{ESC}_{\text {endo }}$ proliferation in a transwell system [25]. In contrast, Xu et al. reported that umbilical cord-MSC (UC-MSC) significantly reduce proliferation of $\mathrm{ESC}_{\text {cyst }}$ [26]. These discrepancies between the studies may be explained by the different tissue sources for derivation of MSC, which has previously been described [27]. There are no other studies examining the effects of MSC on ESC in terms of proliferation. However, MSC have been previously shown to increase the cell proliferation of other cell types through their release of cytokines, and growth factors [28-30]. In our study, conditioned medium induced proliferation significantly of both $\mathrm{ESC}_{\text {endo }}$ and $\mathrm{ESC}_{\text {cyst }}$. In contrast, the transwell system had no effect on the proliferation of $\mathrm{ESC}_{\text {endo }}$ and $\mathrm{ESC}_{\text {cyst }}$. In the transwell system, there is a paracrine effect between ESC and Ad-MSC; Ad-MSC may become modulated by factors secreted by ESC, subsequently hindering their growth-promoting effects on ESC. Paracrine signaling is the local cell-to-cell communication through the paracrine factors (e.g., cytokines, hormones, and microvesicles) that are secreted into the extracellular environment 

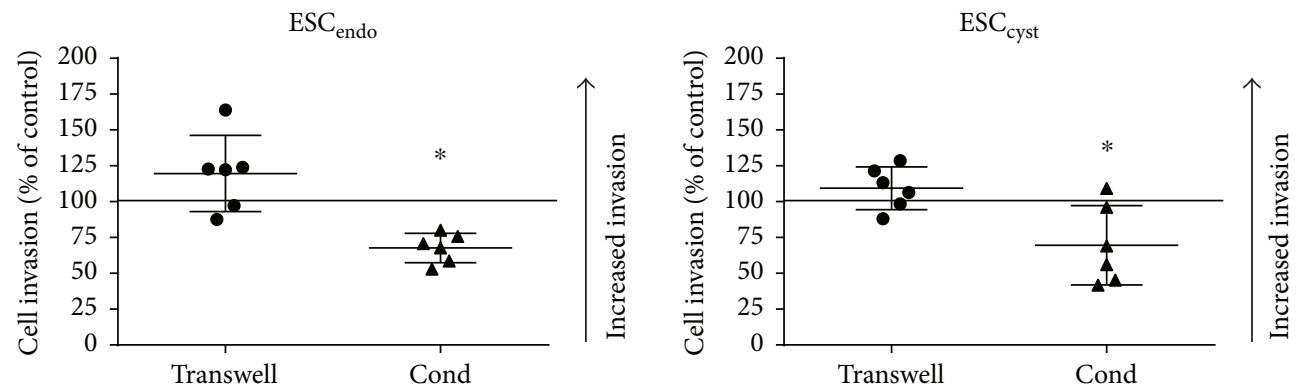

(a)


(b)
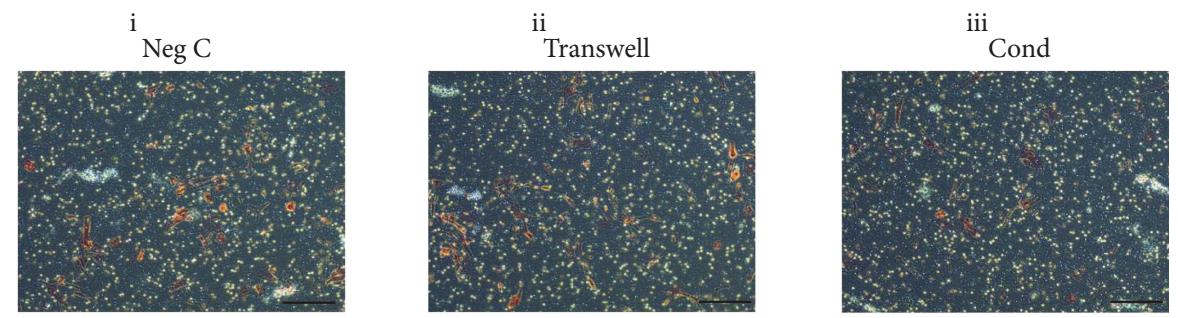

(c)

FIGURE 7: Ad-MSC did not increase invasion of $\mathrm{ESC}_{\text {endo }}$ and $\mathrm{ESC}_{\text {cyst }}$. A transwell system using Ad-MSC and conditioned medium (Cond) from allogeneic Ad-MSC were used in coculture with $\mathrm{ESC}_{\text {endo }}$ or $\mathrm{ESC}_{\text {cyst. }}$. Following cell coculture, invasion of $\mathrm{ESC}_{\text {endo }}$ and $\mathrm{ESC}_{\text {cyst }}$ was determined using the transwell invasion assay after 20 hours. Conditioned medium reduced invasion of $\mathrm{ESC}_{\text {endo }}$ and $\mathrm{ESC}_{\mathrm{cyst}}\left({ }^{*} P<0.05\right)$. Representative images of invasion for each condition for $\mathrm{ESC}_{\text {endo }}$ (b) and $\mathrm{ESC}_{\mathrm{cyst}}$ (c). The $0.4 \mu \mathrm{m}$ pores of the inserts are the white dots, and the invaded cells are light/dark red in color (10x magnification). The data was normalized to untreated controls for each cell type. Three independent experiments ( $n=3$ biological replicates) were carried out in duplicates (mean \pm SD).

[31]. This feedback effect is absent in the conditioned medium, which contains factors secreted by unmodulated Ad-MSC. This may explain the different results from the transwell, and the conditioned medium systems in this study. Moreover, it is unlikely that the conditioned medium effect was nonspecific; instead, it is most likely specific for AdMSC since the effects with conditioned medium differ from the untreated controls. The direct cell coculture system had no effect, or caused a significant decrease in the proliferation of $\mathrm{ESC}_{\text {endo }}$ and $\mathrm{ESC}_{\text {cyst }}$. The decrease in cell proliferation could be due to the growth inhibitory effects of MSC through direct contact. As previously shown, MSC mediate their greatest inhibition on cell proliferation in vitro through direct contact compared to the transwell system [32].

In this study, Ad-MSC significantly decreased apoptosis, and increased survival of $\mathrm{ESC}_{\text {endo }}$ and $\mathrm{ESC}_{\text {cyst }}$, which is in keeping with studies in other cell types [33-35]. These results suggest that Ad-MSC may decrease apoptosis, increase survival of $\mathrm{ESC}_{\text {endo }}$ and $\mathrm{ESC}_{\text {cyst }}$, and may support endometriosis. In contrast, UC-MSC have been reported to induce apoptosis of $\mathrm{ESC}_{\text {cyst }}$ in a transwell system by a mechanism involving the tensin homologue gene (PTEN), an important housekeeping gene in endometrial tissue [26]. This discrepancy to our study may be due to the use of a different source of MSC [27].

Cell adhesion is crucial in the development of endometriosis to allow the attachment of endometrial tissue onto the mesothelial lining in the pelvic cavity following retrograde menstruation. Treatment via the transwell system was found to cause a significant increase in the adhesion of $\mathrm{ESC}_{\text {endo }}$, but it had no effect on the adhesion of $\mathrm{ESC}_{\text {cyst }}$. Conditioned medium caused a significant decrease in the adhesion of

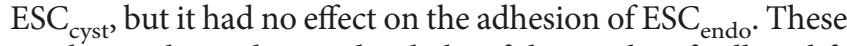
results can be understood in light of the results of cell proliferation, since it is known that cells that divide rapidly are likely to be less adherent [36]. Moreover, the results may be explained by differences between the transwell and the conditioned medium systems; there is a paracrine effect in the transwell system that is absent in the conditioned medium as described above. To our knowledge, there are no other studies in the literature that have examined the effects of MSC on the adhesion of $\mathrm{ESC}_{\text {endo }}$ and $\mathrm{ESC}_{\text {cyst }}$. 
The tube formation assay is commonly used to quantify the effects of various treatments on the ability of HUVEC to form tubes on a gelled membrane matrix as an in vitro model of angiogenesis [20]. Conditioned medium collected from Ad-MSC/ESC endo $_{\text {and Ad-MSC/ESC }}$ cyst cell cocultures significantly induced tube formation of HUVEC compared to untreated controls. There are no previous studies that have examined the outcome of MSC-treated $\mathrm{ESC}_{\text {endo }}$ and $\mathrm{ESC}_{\text {cyst }}$ on HUVEC tube formation. Our results are in line with previous reports showing that MSC have the ability to increase tube formation [37-39].

The transwell system significantly increased the migration of $\mathrm{ESC}_{\text {cyst }}$ compared to the untreated control but had no effect on $\mathrm{ESC}_{\text {endo. }}$. Moreover, the transwell system had no effect on the invasion of either cell type. Meanwhile, the conditioned medium system significantly decreased the migration and invasion of both $\mathrm{ESC}_{\text {endo }}$ and $\mathrm{ESC}_{\mathrm{cys}}$. Migration and invasion require initial cell adherence, and therefore, these results are in line with the cell adhesion data and may be explained by differences between the transwell and the conditioned medium systems [40]. The transwell system has a paracrine effect that is absent in the conditioned medium, as described above. Only one previous study has examined the effect of MSC conditioned medium on the migration and invasion of $\mathrm{ESC}_{\text {endo }}$ and $\mathrm{ESC}_{\text {cyst }}$ [24]. In contrast to our results, they found that migration and invasion of both cell types were significantly increased compared to untreated controls [24]. Again, this discrepancy could be explained by the different sources of MSC [27]. Their study used MSC isolated from endometriotic ovarian cysts and the endometrium of women with endometriosis, and we used allogeneic Ad-MSC [24].

The limited number of donors and the donor hormonal status did not affect the consistency of data acquired from the in vitro cell experiments. Statistically significant results were observed and meaningful conclusions could still be drawn. Moreover, a similar number of patients have been used in other studies $[10,41]$. Also, the use of Ad-MSC isolated from the adipose tissue of pregnant women may not be optimal; however, it has been previously shown that pregnancy has no detrimental effects on the nature of the isolated Ad-MSC [42]. Nevertheless, it must be remembered that this is an in vitro study, and additional in vitro and in vivo studies are needed to validate the findings of the current study. The present study suggests that allogeneic Ad-MSC should not be used as a potential therapy for endometriosis, because they may support the pathology of endometriosis by maintaining and increasing growth of ectopic endometrial tissue. In addition, since MSC are present in ectopic lesions in endometriosis, this means they are likely involved in the pathogenesis of endometriosis. This is the most extensive in vitro study showing that this may indeed be true, and will be significant in further understanding the pathogenesis of endometriosis to potentially find new therapeutics by targeting MSC.

\section{Conclusion}

In conclusion, Ad-MSC should not be considered as a potential therapy for endometriosis with endometriotic ovarian cysts, because they may promote proliferation, survival, and migration of $\mathrm{ESC}_{\mathrm{cyst}}$ and support $\mathrm{ESC}_{\mathrm{cys}}$ to promote angiogenesis of endothelial cells to worsen the pathology. However, further studies examining other sources of MSC are needed to confirm if MSC are indeed an ineffective therapy for endometriosis.

\section{Conflicts of Interest}

The authors declare that there is no conflict of interests regarding the publication of this paper.

\section{Authors' Contributions}

Fawaz Abomaray, Sebastian Gidlöf, and Cecilia Götherström contributed to the idea and design of the paper. Fawaz Abomaray contributed to the data acquisition. Fawaz Abomaray, Sebastian Gidlöf, and Cecilia Götherström contributed to the data analysis and interpretation. Fawaz Abomaray performed the laboratory assays. Fawaz Abomaray, Sebastian Gidlöf, and Cecilia Götherström wrote the paper and revised it critically. Fawaz Abomaray, Sebastian Gidlöf, Bartosz Bezubik, Mikael Engman, and Cecilia Götherström proofread the manuscript. All the authors read and approved the final paper.

\section{Acknowledgments}

The authors thank the staff and patients at the Women's Clinic at Karolinska University Hospital for their help in obtaining and donating adipose, endometrial, and endometriotic ovarian cyst tissue. This study was supported by King Abdulla International Medical Research Centre, Stockholm County Council, and Karolinska Institutet.

\section{References}

[1] C. Mehedintu, M. N. Plotogea, S. Ionescu, and M. Antonovici, "Endometriosis still a challenge," Journal of Medicine and Life, vol. 7, no. 3, pp. 349-357, 2014.

[2] P. Vercellini, P. Vigano, E. Somigliana, and L. Fedele, "Endometriosis: pathogenesis and treatment," Nature Reviews Endocrinology, vol. 10, no. 5, pp. 261-275, 2014.

[3] R. O. Burney and L. C. Giudice, "Pathogenesis and pathophysiology of endometriosis," Fertility and Sterility, vol. 98, no. 3, pp. 511-519, 2012.

[4] S. Sourial, N. Tempest, and D. K. Hapangama, "Theories on the pathogenesis of endometriosis," International Journal of Reproductive Medicine, vol. 2014, Article ID 179515, 9 pages, 2014.

[5] H. Liu and J. H. Lang, "Is abnormal eutopic endometrium the cause of endometriosis? The role of eutopic endometrium in pathogenesis of endometriosis," Medical Science Monitor, vol. 17, no. 4, pp. RA92-RA99, 2011.

[6] T. Squillaro, G. Peluso, and U. Galderisi, "Clinical trials with mesenchymal stem cells: an update," Cell Transplantation, vol. 25, no. 5, pp. 829-848, 2016.

[7] A. Dorronsoro, J. Fernandez-Rueda, K. Fechter et al., "Human mesenchymal stromal cell-mediated immunoregulation: 
mechanisms of action and clinical applications," Bone Marrow Research, vol. 2013, Article ID 203643, 8 pages, 2013.

[8] R. Yanez, M. L. Lamana, J. Garcia-Castro, I. Colmenero, M. Ramirez, and J. A. Bueren, "Adipose tissue-derived mesenchymal stem cells have in vivo immunosuppressive properties applicable for the control of the graft-versus-host disease," Stem Cells, vol. 24, no. 11, pp. 2582-2591, 2006.

[9] G. Constantin, S. Marconi, B. Rossi et al., "Adipose-derived mesenchymal stem cells ameliorate chronic experimental autoimmune encephalomyelitis," Stem Cells, vol. 27, no. 10, pp. 2624-2635, 2009.

[10] S. Nikoo, M. Ebtekar, M. Jeddi-Tehrani et al., "Menstrual blood-derived stromal stem cells from women with and without endometriosis reveal different phenotypic and functional characteristics," Molecular Human Reproduction, vol. 20, no. 9, pp. 905-918, 2014.

[11] F. Abomaray, S. Gidlöf, and C. Götherström, "Mesenchymal stromal cells are more immunosuppressive in vitro if they are derived from endometriotic lesions than from eutopic endometrium," Stem Cells International, vol. 2017, Article ID 3215962, 13 pages, 2017.

[12] A. P. Kao, K. H. Wang, C. C. Chang et al., "Comparative study of human eutopic and ectopic endometrial mesenchymal stem cells and the development of an in vivo endometriotic invasion model," Fertility and Sterility, vol. 95, no. 4, pp. 1308-1315.e1, 2011.

[13] S. H. Al-Saqi, M. Saliem, S. Asikainen et al., "Defined serumfree media for in vitro expansion of adipose-derived mesenchymal stem cells," Cytotherapy, vol. 16, no. 7, pp. 915-926, 2014.

[14] E. Aktas, C. S. Chamberlain, E. E. Saether et al., "Immune modulation with primed mesenchymal stem cells delivered via biodegradable scaffold to repair an Achilles tendon segmental defect," Journal of Orthopaedic Research, vol. 35, no. 2, pp. 269-280, 2017.

[15] E. E. Saether, C. S. Chamberlain, E. Aktas, E. M. Leiferman, S. L. Brickson, and R. Vanderby, "Primed mesenchymal stem cells alter and improve rat medial collateral ligament healing," Stem Cell Reviews and Reports, vol. 12, no. 1, pp. 42-53, 2016.

[16] S. Urbani, R. Caporale, L. Lombardini, A. Bosi, and R. Saccardi, "Use of CFDA-SE for evaluating the in vitro proliferation pattern of human mesenchymal stem cells," Cytotherapy, vol. 8, no. 3, pp. 243-253, 2006.

[17] E. Cosimo, A. M. McCaig, L. J. M. Carter-Brzezinski et al., "Inhibition of NF- $\kappa \mathrm{B}$-mediated signaling by the cyclindependent kinase inhibitor CR8 overcomes prosurvival stimuli to induce apoptosis in chronic lymphocytic leukemia cells," Clinical Cancer Research, vol. 19, no. 9, pp. 2393-2405, 2013.

[18] M. A. Borahay, F. Lu, B. Ozpolat et al., "Mullerian inhibiting substance suppresses proliferation and induces apoptosis and autophagy in endometriosis cells in vitro," ISRN Obstetrics and Gynecology, vol. 2013, Article ID 361489, 6 pages, 2013.

[19] P. A. B. Klemmt, J. G. Carver, P. Koninckx, E. J. McVeigh, and H. J. Mardon, "Endometrial cells from women with endometriosis have increased adhesion and proliferative capacity in response to extracellular matrix components: towards a mechanistic model for endometriosis progression," Human Reproduction, vol. 22, no. 12, pp. 3139-3147, 2007.

[20] I. Arnaoutova and H. K. Kleinman, "In vitro angiogenesis: endothelial cell tube formation on gelled basement membrane extract," Nature Protocols, vol. 5, no. 4, pp. 628-635, 2010.
[21] E. A. Jaffe, R. L. Nachman, C. G. Becker, and C. R. Minick, "Culture of human endothelial cells derived from umbilical veins. Identification by morphologic and immunologic criteria," The Journal of Clinical Investigation, vol. 52, no. 11, pp. 2745-2756, 1973.

[22] Y. M. Fortenberry, S. M. Brandal, G. Carpentier, M. Hemani, and A. P. Pathak, "Intracellular expression of PAI-1 specific aptamers alters breast cancer cell migration, invasion and angiogenesis," PLoS One, vol. 11, no. 10, article e0164288, 2016.

[23] A. Moggio, G. Pittatore, P. Cassoni, G. L. Marchino, A. Revelli, and B. Bussolati, "Sorafenib inhibits growth, migration, and angiogenic potential of ectopic endometrial mesenchymal stem cells derived from patients with endometriosis," Fertility and Sterility, vol. 98, no. 6, pp. 1521-1530.e2, 2012.

[24] J. Li, Y. Dai, H. Zhu, Y. Jiang, and S. Zhang, "Endometriotic mesenchymal stem cells significantly promote fibrogenesis in ovarian endometrioma through the $\mathrm{Wnt} / \beta$-catenin pathway by paracrine production of TGF- $\beta 1$ and Wnt1," Human Reproduction, vol. 31, no. 6, pp. 1224-1235, 2016.

[25] X. Yang, M. Zhang, Y. Zhang, W. Li, and B. Yang, "Mesenchymal stem cells derived from Wharton jelly of the human umbilical cord ameliorate damage to human endometrial stromal cells," Fertility and Sterility, vol. 96, no. 4, pp. 10291036.e4, 2011.

[26] L. N. Xu, N. Lin, B. N. Xu, J. B. Li, and S. Q. Chen, "Effect of human umbilical cord mesenchymal stem cells on endometriotic cell proliferation and apoptosis," Genetics and Molecular Research, vol. 14, no. 4, pp. 16553-16561, 2015.

[27] H. Klingemann, D. Matzilevich, and J. Marchand, "Mesenchymal stem cells - sources and clinical applications," Transfusion Medicine and Hemotherapy, vol. 35, no. 4, pp. 2-277, 2008.

[28] J. Mei, X. Y. Zhu, L. P. Jin, Z. L. Duan, D. J. Li, and M. Q. Li, "Estrogen promotes the survival of human secretory phase endometrial stromal cells via CXCL12/CXCR4 up-regulationmediated autophagy inhibition," Human Reproduction, vol. 30, no. 7, pp. 1677-1689, 2015.

[29] Y. Chu, H. Tang, Y. Guo et al., “Adipose-derived mesenchymal stem cells promote cell proliferation and invasion of epithelial ovarian cancer," Experimental Cell Research, vol. 337, no. 1, pp. 16-27, 2015.

[30] F.-X. Yu, W.-J. Hu, B. He, Y.-H. Zheng, Q.-Y. Zhang, and L. Chen, "Bone marrow mesenchymal stem cells promote osteosarcoma cell proliferation and invasion," World Journal of Surgical Oncology, vol. 13, no. 1, p. 52, 2015.

[31] M. Gnecchi, P. Danieli, G. Malpasso, and M. C. Ciuffreda, "Paracrine mechanisms of mesenchymal stem cells in tissue repair," Methods in Molecular Biology, vol. 1416, pp. 123146, 2016.

[32] Y. Z. Paterson, N. Rash, E. R. Garvican, R. Paillot, and D. J. Guest, "Equine mesenchymal stromal cells and embryoderived stem cells are immune privileged in vitro," Stem Cell Research \& Therapy, vol. 5, no. 4, p. 90, 2014.

[33] X.-B. Wu, Y. Liu, G.-H. Wang et al., "Mesenchymal stem cells promote colorectal cancer progression through AMPK/ mTOR-mediated NF- $\kappa$ B activation," Scientific Reports, vol. 6, no. 1, article 21420, 2016.

[34] Y. Z. Zhang, J. Y. Lou, H. Y. Bai, Y. L. Wang, J. F. Li, and H. L. Yin, "Protective effect of bone marrow mesenchymal stem cells on PC12 cells apoptosis mediated by TAG1," International Journal of Clinical \& Experimental Pathology, vol. 8, no. 10, pp. 12093-12100, 2015. 
[35] M. E. Healy, R. Bergin, B. P. Mahon, and K. English, "Mesenchymal stromal cells protect against caspase 3-mediated apoptosis of $\mathrm{CD}_{1} 9^{+}$peripheral B cells through contactdependent upregulation of VEGF," Stem Cells and Development, vol. 24, no. 20, pp. 2391-2402, 2015.

[36] L. Bacakova, E. Filova, M. Parizek, T. Ruml, and V. Svorcik, "Modulation of cell adhesion, proliferation and differentiation on materials designed for body implants," Biotechnology Advances, vol. 29, no. 6, pp. 739-767, 2011.

[37] P. Kuchroo, V. Dave, A. Vijayan, C. Viswanathan, and D. Ghosh, "Paracrine factors secreted by umbilical cordderived mesenchymal stem cells induce angiogenesis in vitro by a VEGF-independent pathway," Stem Cells and Development, vol. 24, no. 4, pp. 437-450, 2015.

[38] I. Arutyunyan, T. Fatkhudinov, E. Kananykhina et al., "Role of VEGF-A in angiogenesis promoted by umbilical cord-derived mesenchymal stromal/stem cells: in vitro study," Stem Cell Research \& Therapy, vol. 7, no. 1, p. 46, 2016.

[39] Y. N. Li, L. Guo, H. S. Ahn, M. H. Kim, and S.-W. Kim, “Amniotic mesenchymal stem cells display neurovascular tropism and aid in the recovery of injured peripheral nerves," Journal of Cellular and Molecular Medicine, vol. 18, no. 6, pp. 10281034, 2014.

[40] C. R. Justus, N. Leffler, M. Ruiz-Echevarria, and L. V. Yang, "In vitro cell migration and invasion assays," Journal of Visualized Experiments, no. 88, 2014.

[41] M. Jafarabadi, M. Salehnia, and R. Sadafi, "Evaluation of two endometriosis models by transplantation of human endometrial tissue fragments and human endometrial mesenchymal cells," International Journal of Reproductive BioMedicine, vol. 15, no. 1, pp. 21-32, 2017.

[42] L. W. C. Ng, S. K. Yip, H. K. Wong et al., "Adipose-derived stem cells from pregnant women show higher proliferation rate unrelated to estrogen," Human Reproduction, vol. 24, no. 5, pp. 1164-1170, 2009. 


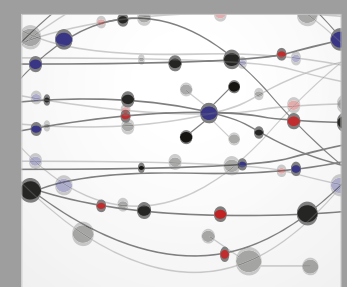

The Scientific World Journal

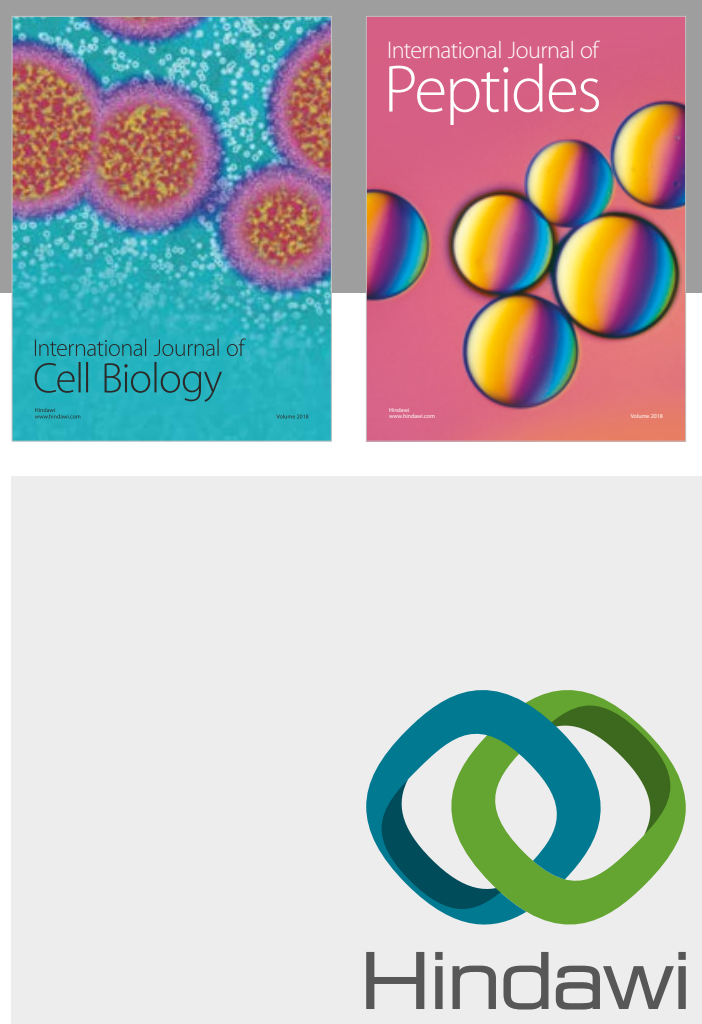

Submit your manuscripts at

www.hindawi.com
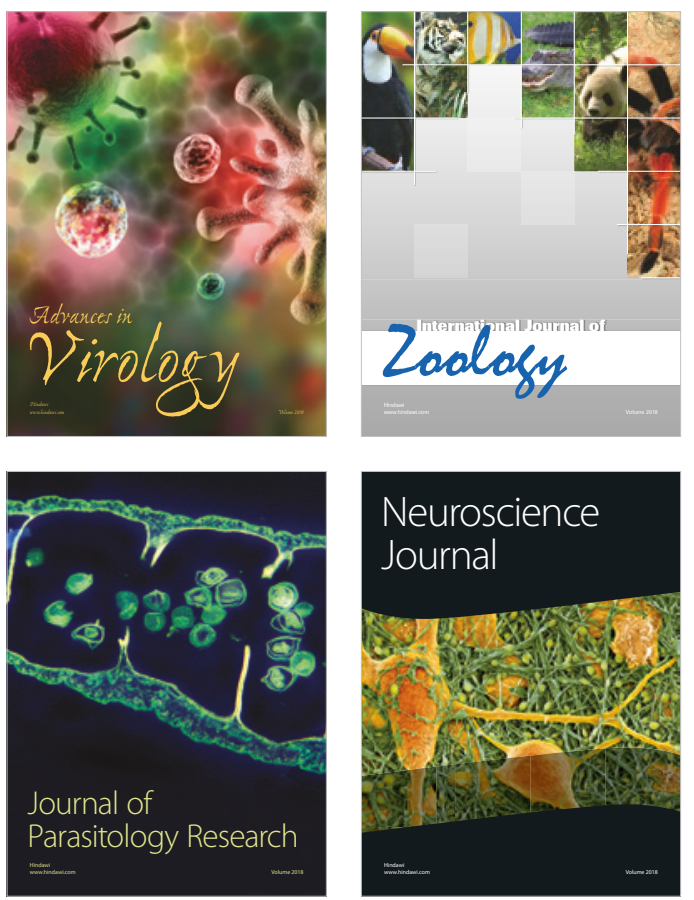
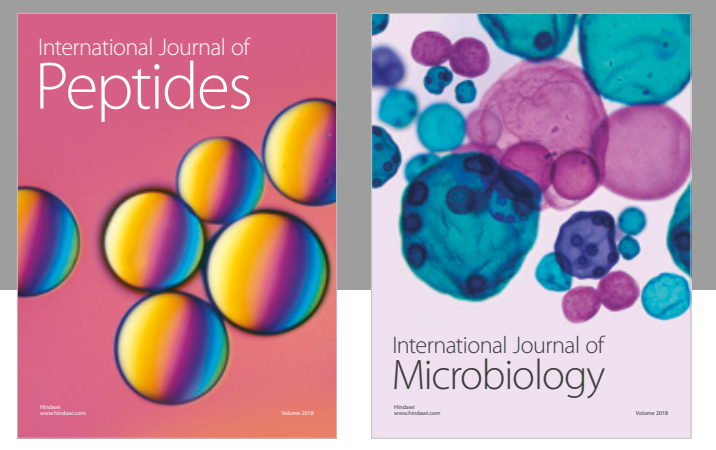

nternational Journal of Microbiology
Journal of
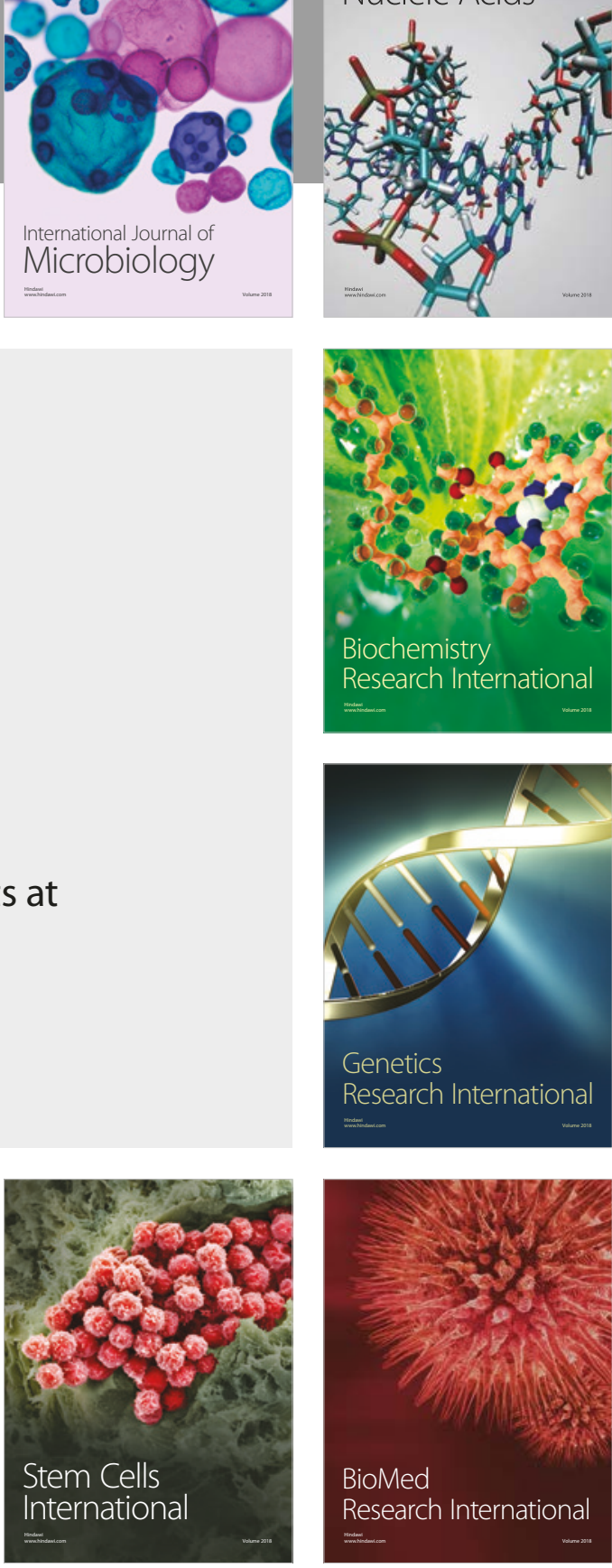
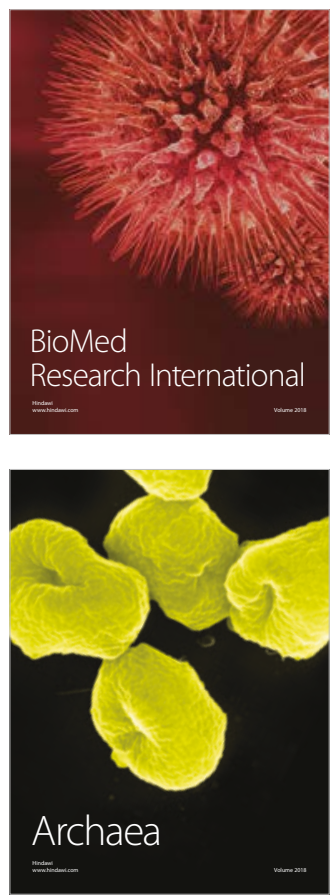